\title{
Thinking and exploration on constructing an innovated guidance model of school-enterprise collaborative students' graduation projects
}

\author{
Chunfang Xiang \\ College of Art and Design, Wuchang Institute of Technology, Wuhan Hubei, 430000, China
}

Keywords: School-enterprise collaborative, Graduation project, Innovative guidance, Model.

\begin{abstract}
Under the School-enterprise collaborative mode an innovative guidance on graduation projects in colleges and universities for construction of scientific guidance model can not only help students' analytical and problem-solving ability get cultivated, their innovation capability get intensified correspondingly, but can also bring relevant positive impact on the implementation of collaborative innovation thinking and the in-depth development of school-enterprise cooperation. Therefore, colleges and universities should pay more attention to this issue, actively construct an innovated guidance model of school-enterprise collaborative students' graduation projects, and truly improve students' social adaptation ability so as to cultivate students into talents who can satisfy the demand of social construction.
\end{abstract}

\section{Introduction}

Innovation, while playing a significantly guiding role to promote the education quality in colleges and universities, is also the inner developmental requirement for colleges and universities to be in line with world first-class universities positively impacting the realization of innovation-oriented country and the strategy of reinvigorating country with talents. For a long time innovation ability shortage has greatly restricted the sustainable and sound development of Chinese education enterprise and prevented the progress of Chinese scientific and technological society and the improvement of comprehensive national power. Therefore, colleges and universities should further focus more on the innovation education work during educational practice. Only by cultivating students' innovative quality can they truly improve the education quality in colleges and universities and develop high-quality talents for the society. Based on this, college and universities should try to combine the school educational guidance with the enterprise's talent cultivation work when during the process of organizing students for their graduation projects so as to truly establish a school-enterprise collaborative model and promote students' development from three aspects of industry-university-research cooperation. Under this precondition, colleges and universities should explore more innovative graduation project guidance model based on school-enterprise collaboration and strengthen the scientificity of guidance work so as to provide conditions for students to remarkably improve their social adaptation ability.

\section{Advantages of school-enterprise collaborative operating mechanism on exploring the innovative graduation project guidance model}

Analyze from a general aspect, there exists extremely close relation between design and creation. When launching each relevant course in art and design specialty, the cultivation of students' comprehensive practical should be an important attention so as to promote students can gradually develop their own operation ability during the process of participating social related practice and improve students' innovation awareness and creative ability so as to truly realize their innovative development in practice and their growth in creation and to lay solid foundation for students to obtain bigger career development achievements in the future. In current stage, with the ever-changing demand for talents in the society, colleges and universities have gradually realized problems existing in current talent cultivation mode in their talent development work and the rigid and outdated thinking cannot satisfy the realistic demands for talent development in current stage so that it is 
urgently necessary to strengthen the dynamic integration of industry-university-research cooperation and provide relevant chances for students' internship and study so as to make sure that colleges students' own practical ability and knowledge application capability can be adequately intensified after systematic study and then to make bigger contribution for social construction in their work life. Generally speaking, there are some advantages of innovation on college graduation project guidance model based on school-enterprise collaboration as below:

Firstly, make an in-depth analysis from the perspective of teachers. Schools' application of school-enterprise collaborative graduation project guidance model can help faculty advisers in the school truly go deep into enterprises to study in inner-enterprise, and meanwhile undertake relevant teaching, scientific research, and production tasks so that teachers' knowledge structure, ability structure and quality structure will surely be optimized. Moreover, it will form a relevant organic guidance framework as a while and help teachers master relevant concepts of enterprise and market-oriented economy based on owning certain teaching abilities. They can make reasonable innovation on graduation guidance work by combing their own professional experience in enterprises and gradually form market innovation awareness and innovative design ability on the basis of guaranteeing the effect students' learning basic knowledge so as to lay foundation for students to develop innovation ability and make sure their innovative potentials can be excavated utmost ${ }^{[1]}$.

Secondly, make an in-depth analysis from the perspective of students. Schools' suitable application of industry-school-research integrated collaborative education model in educational practice can help the new achievements obtained in production and scientific research well combined with social economic construction, help students to complete their understanding of knowledge from sensibly to rationally during the process of exploration analysis and knowledge application, and finally help them to achieve the breakthrough of their practical ability cultivation so as to lay solid foundation for students to carry out good social life in the future. Meanwhile, based on rational understanding students have possessed, their own practical ability, innovation ability and problem-solving ability will be intensified during the process of participating in school-enterprise cooperation together with teachers. This will help students' professional adaptive ability to constantly improve and lay foundation for students to carry out future scientific research innovation work.

Lastly, for enterprise, school-enterprise teaching mode is that schools make optimized adjustment on their own talent cultivation mode by combing enterprises' practical developmental demands during the process of educational practice. They even directly invite professionals or senior technical staffs in enterprises to give lessons to students for the purpose that students can have a deep understanding on relevant knowledge and help students to make scientific innovation on their own comprehensive quality cultivation through combining the working experience of technical staffs, for the convenience that students can gradually improve their own practical ability on the basis of updating theoretical knowledge and to create conditions for their own future development. Based on this, enterprise technical staffs can instruct some innovative knowledge when teaching them. In this way, it can help to gradually transform scientific research achievements into enterprise's real productivity under the influence of educational practice so as to gain more economic and social benefits during the practical development process.

\section{School-enterprise collaboration oriented students' graduation project innovation operation mode}

School-enterprise collaborative operation mechanism has significantly important impact on the development of students' practical ability and deepening development of college education reform. Normlization management of school-enterprise collaborative operation mechanism will help to further improve teaching resource and teaching quality and completion of software and hardware facilities so as to guide students' innovative ability to be remarkably intensified. 
Innovative guidance of teachers' comprehensive quality in colleges and universities will have decisive influence on graduation project guidance work

During the critical period based on the graduation innovation guidance mode established by school-enterprise collaboration and the regular operation of this guidance model, schools should adequately hire relevant senor management staffs and technical staffs in schools for specific instruction during the process of students' receiving educational guidance so as to truly provide corresponding guarantee for the sharing of school-enterprise advanced technologies ${ }^{[2]}$. In current stage, with the further development of educational reform innovation work in Chinese colleges and universities, construction of double-teaching advisors has become the backup force of art and design specialty during feasible innovation of graduation projects. College teachers focus on the teaching of theoretical knowledge to students to provide high-quality professional education so that teachers introduced by enterprises will pay more attention to developing students' knowledge application ability with the hope that through instruction of practical experience and organizing students to participating various social practical activities students' practical ability can be improved correspondingly. In this way, an educational guidance mode focusing both theoretical and practical knowledge can be truly established in college educational practice to make sure that students can successfully complete their graduation projects under the guidance and instructions from teachers and can further improve the quality of their graduation projects.

\section{Scientifically selecting graduation project topic can help a dynamic integration between education and research development with enterprise practice}

The implementation of scientifically selecting graduation project topic is the precondition to guarantee the quality of students' whole graduation project. Relevant educational experts must analyze from the perspective of students' learning demand and reasonably select the project topics based on the basic teaching contents. In this way, students can form deep understanding of graduation project during their practical research so as to effectively improve their innovation in the graduation projects ${ }^{[3]}$. Generally speaking, at present graduation project topic selection in Chinese colleges and universities mainly include some issues as below: knowledge system they have mastered is relatively backward; schools do not pay attention to the openness in the talent cultivation by only working blindly so that education practicability is poor; there are lot of written graduation projects so that students lack chances to take actions and operations. To gradually solve issues mentioned above through corresponding teaching adjustment, schools should strengthen the application of innovative education platform based on the school-enterprise collaborative education thinking to make correct guidance for students in their graduation innovation work so that they can truly apply their knowledge after receiving the instruction of graduation innovation guidance mode and gain solid foundation for their future better development.

\section{Take the initiative to finish graduation project task and display the practical innovation advantages of graduation projects}

For college students, graduation projects are what they should do in the last practical learning stage of college life. But this practical procedure is with extremely strong integrity and initiative. Seen from the essential property of design, it equals to creation to some extent and creation is the soul of artistic design. Works designed with creations can own personalized ideological connotation to show the unique artistic value. Under the influenced of school-enterprise collaborative thinking, teaching guidance Chinese college students received after entering higher educational stage is a professional course teaching based on industry-school-research integration. In the teaching process, the planning of professional teaching and advanced setting of intern courses can integrate detailed teaching contents, plan and social practice and relevant scientific research organically and help students personally participate into relevant social practice through importing enterprise's relevant projects and programs to truly realize the organic combination of professional teaching, scientific research and social practice. In this way, students can obtain a large amount of experiential learning chances to 
lay solid foundation for them to obtain better occupational experience after graduation. In a word, optimization and reform of talent cultivation mode and graduation innovation guidance mode in colleges and universities firstly requires to develop students' innovation consciousness and ability as the core content in talent cultivation work so as to conduct specific instruction and guidance for students according to their different learning demands and growing features, and to help them have correct development direction on the basis of improving students' innovation ability. Only in this way can students gradually apply the leading-edge information learned during the practical process in enterprises professional knowledge and capabilities learned in school education into graduation project practice to fully stimulate their potentials and make artistic creation during completing their graduation project so as to truly develop into a project topic showing own advantages in each procedure of the project practice ${ }^{[4]}$. In addition, to truly guarantee the effect of students' artistic design, schools should guide students to establish correct design objective so as to help them develop the sensibility to know updates within industry and some new materials and to lay solid foundation for students' future healthy and sound development while improving their practical working ability.

\section{Problems to be noticed when applying school-enterprise collaborative guidance thinking}

Practical researches have proved that during the process of establishing graduation project innovation guidance mode in colleges and universities, the application of school-enterprise collaborative guidance thinking can be used to significantly promote students' own innovation ability when participating in graduation project work and to indicate correct development direction for school's innovative talent cultivation under the guidance of innovation thinking. Based on this, some problems should be noticed during the process of implementing school-enterprise collaborative teaching mode.

First is to adhere to the principle of advancing with the times when launching education work and to form more profound understanding of the importance of college educational practice based on the demand of innovation talent cultivation to actively establish the concept of developing innovative talents and develop students' practical innovation ability so as to make correct guidance for students to gain sustainable and sound development in the future.

Secondly, personnel department in colleges and universities should set up scientific evaluation target and talent cultivation demands based on the existing school-enterprise collaborative talent cultivation demand through combining the guidance opinions of enterprise's participation into educational training. They should also make optimization and adjustment of the talent selection methods to help teachers to constantly improve their own overall qualities during the process of practical study so as to provide corresponding human resource guarantee for the intensification of education quality ${ }^{[5]}$.

The last point is to construct a relatively perfected off-campus internship base. Schools' construction of graduation project innovation guidance work under educational development demands and guidance of school-enterprise collaborative thinking will also require more steady off-campus internship base to satisfy college graduates' innovation development demands during the process of their graduation projects. Meanwhile to guarantee the quality of students' innovation ability cultivation, schools should pay attention to selecting high-quality training bases so that students' own innovation ability can be truly cultivated during the process of participating practical trainings.

\section{Conclusion:}

To sum up, establishment of innovated guidance model of school-enterprise collaborative students' graduation projects can help students improve their own social practical ability on the basis of mastering basic learning ability to develop their problem-solving ability and innovation ability correspondingly, but can also deepen collaborative innovation based on this so as to promote further development of talents cultivation work in Chinese colleges and universities, develop more 
high-quality talents for social construction and provide human resource guarantee for the sustainable and healthy development of Chinese economic society.

\section{Acknowledgement}

This thesis is the provincial teaching research project of institutions of higher learning in Hubei with the title of "School-enterprise collaborative developmental research on the graduation project curriculum of major of art design in civilian-run schools". Project No. 2015444

\section{Reference}

[1] Lv Lan. School-enterprise collaborative innovation, promote the reform in graduation project of business English in higher vocational colleges, Education for Chinese After-school (early period), 2014(z1):979-979.

[2] An Qingda, Wei Li, Liu Na, etc. Research on industry-school-research collaborated chemical practical education system, Education Forum, 2014(30):162-163,164.

[3] Wang Hui. Exploration of undergraduate graduation project innovation model in mechanical major based on school-enterprise cooperative guidance, Career Horizon, 2014, 10(7):85-87.

[4] Sun Dali. Strategy analysis college students' innovation and entrepreneurship education in design major, Art Education Research,2013(18):72-74.

[5] Chen Kaibing, Ji Guomin, Li Xiaoyuan, etc. Exploration of graduation project innovation in vocational colleges, Vocational and Technical Education, 2015(2):39-41. 